\title{
Relationship between Neutrophil Lymphocyte Ratio in Children with H. Pylori and Non H. Pylori Gastritis
}

\author{
M Riza Deyuga, Supriatmo, ${ }^{\mathrm{a}}$ Aridamuriany D Lubis, ${ }^{\mathrm{b}}$ Isti Ilmiati Fujiati, \\ Oke Rina Ramayani, Rita Evalina \\ rizadeyuga17@gmail.com
}

Resident of Department of Child Health, Medical School, University of Northern Sumatera, /Adam Malik Hospital, Medan ${ }^{a}$ Gastroenterohepatology Consultant of Department of Child Health, ${ }^{b}$ Emergency and Internsive Care Consultant of Department of Child Health Medical School, University of Northern Sumatera /Adam Malik Hospital, Medan

\begin{abstract}
Helicobacter pylori infection occurs in about $50 \%$ of the world's population and most infections occur during childhood. This infection involves local inflammation in the stomach and a systemic humoral immune response that causes an increase in the number of neutrophils and a decrease in the number of lymphocytes. This study aims to determine the relationship between the value of the Neutrophil Lymphocyte Ratio in children with H. pylori infection and non-H. pylori infection. This cross-sectional analytical study involved 96 children aged 2-18 years who met the research criteria, blood was drawn and HPSA examination was performed, followed by bivariate analysis using the chi square test. The results showed that the subjects were $11.66 \pm 3.69$ years old, most of them were female $(63.5 \%)$, with 51 children $(53.1 \%)$ found to be positively infected with $\mathrm{H}$. pylori. No significant relationship was found between the ratio of neutrophil lymphocytes and $\mathrm{H}$. pylori infection $(\mathrm{p}=0.509)$.
\end{abstract}

Keywords: Pediatric gastritis, Helicobacter pylori infection, neutrophil to lymphocyte ratio

\section{Introduction}

Helicobacter pylori is one of the most common chronic bacterial infections in the world (Yulida, Oktaviyanti and Rosida., 2013). Most infections occur during childhood, with a reported prevalence of 50-80\% among children in Latin America and Africa, and 25\% in the United States. H. pylori causes local inflammation in the stomach and a systemic humoral immune response. The majority of cases have asymptomatic chronic inflammation (Rugierro., 2010). H. pylori infection attracts neutrophils and lymphocytes with several chemotactic proteins released in the gaster. Several substances secreted by mononuclear cells and neutrophils cause mucosal inflammation. As a result, neutrophils, macrophages, and lymphocytes infiltrate the gastric mucosa accompanied by activation of several cytokine signals so that low-level inflammation occurs.

The physiological response of leukocytes in the circulation to stress causes an increase in the number of neutrophils and a decrease in the number of lymphocytes. Changes occur in circulating leukocyte levels during the inflammatory response. Neutrophilia with relative lymphopenia. Neutrophil to lymphocyte ratio (NLR) was obtained from a simple hemogram (Guclu and Agan., 2017). The neutrophil/lymphocyte ratio (NLR) is a recently studied indicator to determine the severity of various diseases, gastric cancer, and H. pylori infection (Liu and Li, 2019; Jafarzadeh, et.al., 2013). Serum neutrophil/lymphocyte ratio (NLR) is a relatively simple, safe, and noninvasive marker of acute inflammation. This study aimed to assess the relationship between the value of the Neutrophil Lymphocyte Ratio in children with H. pylori and non-H. pylori infection. 


\section{Methods}

\subsection{Study and Methods}

This study used an analytical research method with a cross sectional approach in the pediatric gastrohepatology outpatients clinic and pediatric ward of H. Adam Malik Hospital Medan, North Sumatra University Hospital from November to February 2020. The samples which met the inclusion and exclusion criteria were collected by consecutive sampling method with the sample size calculated by the formula with a cross sectional approach. The inclusion criteria include: (a) Age 2-18 years (b) diagnosed with gastritis; exclusion criteria include: (a) Patients with other infectious diseases not related to gastritis (b) Patients with a history of blood disorders or other autoimmune diseases (c) Patients who have received H. pylori eradication therapy.

Children aged 2-18 years with complaints of abdominal pain or repeated vomiting, were then selected by and demographic data were taken (age, gender, and economic status) regarding current complaints, previous illness history, medication history, maternal pregnancy history, birth history, and history of growth and development. A physical examination was carried out including measurements of height and weight to evaluate nutritional status and routine laboratory examinations of blood, liver function, kidney function, and blood sugar, to evaluate the exclusion criteria in this study. Then the patient will be examined for Helicobacter pylori Stool Antigen (HpSA) Test to confirm the diagnosis of Helicobacter pylori infection. This study was approved by the Ethics Committee of the Faculty of Medicine, Universitas Sumatera Utara / Haji Adam Malik General Hospital in Medan.

\subsection{Statistical Analysis}

The program used is SPSS version 22. Univariate analysis to determine the characteristics of H. pylori gastritis patients and the prevalence of $\mathrm{H}$. pylori gastritis in children. Bivariate analysis was used to determine the relationship between NLR results with Helicobacter pylori infection and nutritional status using the chi square test. $p<0.05$ was considered statistically significant.

\section{Result}

This study was followed by 96 children with symptoms of gastritis who had met the inclusion and exclusion criteria. All respondents (100\%) are willing to do the HPSA Test. 51 respondents $(53.1 \%)$ were found to be positive for $\mathrm{H}$. pylori infection, with 45 respondents (46.9\%) not having $\mathrm{H}$. pylori infection in this examination.

Of the 96 respondents analyzed, 61 children were female (63.5\%). The mean age of the subjects was 11.66 years with the youngest age being 2.8 years and the oldest being 17.8 years. The average weight and height of the subjects were $37.04 \mathrm{~kg}$ and $137.34 \mathrm{~cm}$. The most clinical symptom was abdominal pain as many as 55 samples $(57.3 \%)$. The majority of patients had normal nutritional status $(78.1 \%)$. Of the 96 respondents, 51 cases $(53.1 \%)$ of gastritis were caused by $\mathrm{H}$. pylori infection. The characteristics of the subjects are presented in table 1 . 
Table 1. Characteristics of Research Subjects

\begin{tabular}{|c|c|}
\hline Subject Characteristics & $n=96$ \\
\hline \multicolumn{2}{|l|}{ Gender, n (\%) } \\
\hline Man & $35(36.5)$ \\
\hline Woman & $61(63.5)$ \\
\hline \multicolumn{2}{|l|}{ Age, years } \\
\hline Average & 11.66 \\
\hline median & 12.6 \\
\hline $\mathrm{SD}$ & 3.69 \\
\hline Min - mak & $2.8-17.8$ \\
\hline \multicolumn{2}{|l|}{ Body weight, kg } \\
\hline Average & 37.04 \\
\hline median & 36.75 \\
\hline SD & 13.58 \\
\hline Min - mak & $9-85$ \\
\hline \multicolumn{2}{|l|}{ Height, $\mathrm{cm}$} \\
\hline Average & 137.34 \\
\hline median & 143 \\
\hline SD & 18.44 \\
\hline Min - mak & $84-170$ \\
\hline \multicolumn{2}{|l|}{ Clinical Symptoms, n (\%) } \\
\hline Nauseous & $6(6.3)$ \\
\hline Throw up & $22(22.9)$ \\
\hline Vomiting blood & $13(13.5)$ \\
\hline Stomach ache & $55(57.3)$ \\
\hline \multicolumn{2}{|l|}{ Nutritional Status, n (\%) } \\
\hline Malnutrition & $2(2.1)$ \\
\hline Malnutrition & $8(8.3)$ \\
\hline Normal nutrition & $75(78.1)$ \\
\hline More nutrition & $9(9.4)$ \\
\hline Obesity & $2(2.1)$ \\
\hline \multicolumn{2}{|l|}{ H. pylori, n (\%) } \\
\hline Positive & $51(53.1)$ \\
\hline Negative & $45(46.9)$ \\
\hline
\end{tabular}

Of the 35 child subjects with male sex, there were 16 children $(45.7 \%)$ with $\mathrm{H}$. pylori $(+)$ while from 61 children with female sex there were 35 children $(57.4 \%)$ with $\mathrm{H}$ pylori $(+)$. By using the Chi Square test, there was no relationship between gender and the incidence of H. pylori $(p=0,270)$. Based on age, the mean age of children with $H$. pylori $(+)$ was 11.55 years, the mean age of children with $\mathrm{H}$. pylori (-) was 11.79 years. There was no significant age relationship $(\mathrm{p}=0.727)$ between age and the incidence of $\mathrm{H}$. pylori after being analyzed using the Mann Whitney test. The mean weight and height in the group of children with H. pylori (+) were 36.38 $\mathrm{kg}$ and $137.59 \mathrm{~cm}$ and in the group of children with $\mathrm{H}$. pylori (-) the mean weight and height were $36.47 \mathrm{~kg}$ and $135.68 \mathrm{~cm}$, respectively. There was no association between weight and height with H. pylori ( $p>0.05$ ). Table 2 presents the characteristics of the subjects based on the presence of H. pylori. 
Table 2. Characteristics of Research Subjects based on H. pylori infection

\begin{tabular}{|c|c|c|c|}
\hline \multirow{2}{*}{ Subject Characteristics } & \multicolumn{2}{|c|}{ H. pylori } & \multirow{2}{*}{$\mathrm{P}$} \\
\hline & $(+) n=51$ & $(-) n=45$ & \\
\hline \multicolumn{4}{|l|}{ Gender, n (\%) } \\
\hline Man & $16(45.7)$ & $19(54.3)$ & \multirow[t]{2}{*}{$0.270^{\mathrm{a}}$} \\
\hline Woman & $35(57.4)$ & $26(42.6)$ & \\
\hline \multicolumn{4}{|l|}{ Age, years } \\
\hline Average (SD) & $11.55(3.84)$ & $11.79(3.55)$ & \multirow[t]{2}{*}{$0.727^{b}$} \\
\hline Median $(\min -\max )$ & $12.8(2.8-17.8)$ & $12.5(4.4-17.5)$ & \\
\hline \multicolumn{4}{|l|}{ Body weight, $\mathrm{kg}$} \\
\hline Average (SD) & $37.14(15.3)$ & $36.93(11.49)$ & \multirow[t]{2}{*}{$0.942^{\mathrm{c}}$} \\
\hline Median $(\min -\max )$ & $35(9-85)$ & $37.5(9-60)$ & \\
\hline \multicolumn{4}{|l|}{ Height, $\mathrm{cm}$} \\
\hline Average (SD) & $137.06(20.08)$ & $137.67(16.61)$ & \multirow[t]{2}{*}{$0.944^{b}$} \\
\hline Median $(\min -\max )$ & $141(84-168)$ & $145(104-170)$ & \\
\hline \multicolumn{4}{|l|}{ Term, n (\%) } \\
\hline Aceh & $6(54.5)$ & $5(45.5)$ & \multirow[t]{8}{*}{$0.288^{\mathrm{d}}$} \\
\hline Batak & $24(58.5)$ & $17(41.5)$ & \\
\hline India & $1(100)$ & 0 & \\
\hline Java & $6(60)$ & $4(40)$ & \\
\hline Malay & $5(29.4)$ & $12(70.6)$ & \\
\hline Minang & $6(60)$ & $4(40)$ & \\
\hline Papua & $2(100)$ & 0 & \\
\hline Chinese & $1(25)$ & $3(75)$ & \\
\hline \multicolumn{4}{|l|}{ Socio-Economic, n (\%) } \\
\hline Not enough & $8(61.5)$ & $5(38.5)$ & \multirow[t]{2}{*}{$0.513^{\mathrm{a}}$} \\
\hline Good & $43(51.8)$ & $40(48.2)$ & \\
\hline \multicolumn{4}{|l|}{ Children's Education, n (\%) } \\
\hline Kindergarten & $2(33.3)$ & $4(66.7)$ & \multirow[t]{5}{*}{$0.766^{\mathrm{d}}$} \\
\hline Elementary & $22(59.5)$ & $15(40.5)$ & \\
\hline Junior high school & $12(48)$ & $13(52)$ & \\
\hline Senior High School & $11(52.4)$ & $10(47.6)$ & \\
\hline College & $4(57.1)$ & $3(42.9)$ & \\
\hline \multicolumn{4}{|l|}{ Father's Education, n (\%) } \\
\hline Senior High School & $9(50)$ & $9(50)$ & \multirow[t]{2}{*}{$0.768^{\mathrm{a}}$} \\
\hline College & $42(53.8)$ & $36(46.2)$ & \\
\hline \multicolumn{4}{|l|}{ Mother's Education, n (\%) } \\
\hline Senior High School & $5(71.4)$ & $2(28.6)$ & \multirow[t]{2}{*}{$0.442^{\mathrm{e}}$} \\
\hline College & $46(51.7)$ & $43(48.3)$ & \\
\hline \multicolumn{4}{|l|}{ Father's occupation, $\mathrm{n}(\%)$} \\
\hline Employee & $25(48.1)$ & $27(51.9)$ & $0.705^{\mathrm{d}}$ \\
\hline Farmer & $4(80)$ & $1(20)$ & \\
\hline Civil servant & $6(54.5)$ & $5(45.5)$ & \\
\hline TNI/Polri & $3(60)$ & $2(40)$ & \\
\hline Entrepreneur & $13(56.5)$ & $10(43.5)$ & \\
\hline Mother's Occupation, n (\%) & & & \\
\hline Employee & $18(47.4)$ & $20(52.6)$ & $0.274^{\mathrm{d}}$ \\
\hline Farmer & $6(85.7)$ & $1(14.3)$ & \\
\hline Civil servant & $10(66.7)$ & $5(33.3)$ & \\
\hline Entrepreneur & $9(45)$ & $11(55)$ & \\
\hline Housewife & $8(50)$ & $8(50)$ & \\
\hline
\end{tabular}

${ }^{\mathrm{a}}$ Chi square, ${ }^{\mathrm{b}}$ Mann Whitney, ${ }^{\mathrm{c}} \mathrm{T}$ Independent, ${ }^{\mathrm{d}}$ Kruskal Wallis, ${ }^{\mathrm{e}}$ Fischer's Exact

Based on ethnicity, it can be seen that the Indian and Papuan tribes showed 100\% experiencing H. pylori, followed by the Javanese and Minang tribes with a percentage of $60 \%$. No significant relationship was found between ethnicity and the incidence of $\mathrm{H}$. pylori after analysis with the Kruskal Wallis test $(\mathrm{p}=0.288)$.

From 13 Subject of children with low socioeconomic level, there were 8 children (61.5\%) with H. pylori, meanwhile from 83 children with good socioeconomic level, there were 
43 children (51.8\%) with H. pylori. By using Fischer's Exact test, no significant relationship was found between socioeconomic level and the incidence of $H$. pylori $(p=0.513)$.

Based on the level of education of children, the highest percentage with $\mathrm{H}$. pylori is elementary education level of $59.5 \%$ and higher education with a percentage of $57.1 \%$. Based on the analysis using the Kruskal Wallis test, it was shown that there was no relationship between the education level of children and $\mathrm{H}$. pylori $(\mathrm{p}=0.766)$.

Based on the level of parental education, the father's education with the highest percentage of $\mathrm{H}$. pylori patients was a higher education level of $53.8 \%$. Based on the analysis with Chi Square test, it showed that there was no relationship between father's level of education and H. pylori $(p=0.766$ ). Likewise with the education level of the mother, where the highest percentage of patients with $\mathrm{H}$. pylori is a high school education level of $71.4 \%$. Based on the analysis using Fisher's Exact test, it showed that there was no relationship between maternal education level and $\mathrm{H}$. pylori $(\mathrm{p}=0.442)$.

Based on father's and mother's occupations, the highest percentage with H. pylori were farmers, at $80 \%$ and $85.7 \%$, respectively. Based on the analysis using the Kruskal Wallis test, it showed that there was no relationship between father and mother's occupation and H. pylori ( $\mathrm{p}>$ $0.05)$.

A total of 21 people $(72.4 \%)$ in the H. pylori (+) group had a family history of gastritis and 19 people $(61.3 \%)$ in the H. pylori (-) group had a family history of gastritis. There was no significant difference in family history in the two study groups $(\mathrm{p}=0.361)$ after being tested with Chi Square.

Based on nutritional status, the highest percentage of children with $\mathrm{H}$. pylori were children with obesity at $100 \%$ and malnutrition at $75 \%$. The Kruskal Wallis test showed that there was no relationship between nutritional status and H. pylori $(\mathrm{p}=0.318)$.

Table 3. Relationship of Neutrophil Levels, Lymphocytes and Neutrophil Lymphocyte Ratio with H. pylori infection

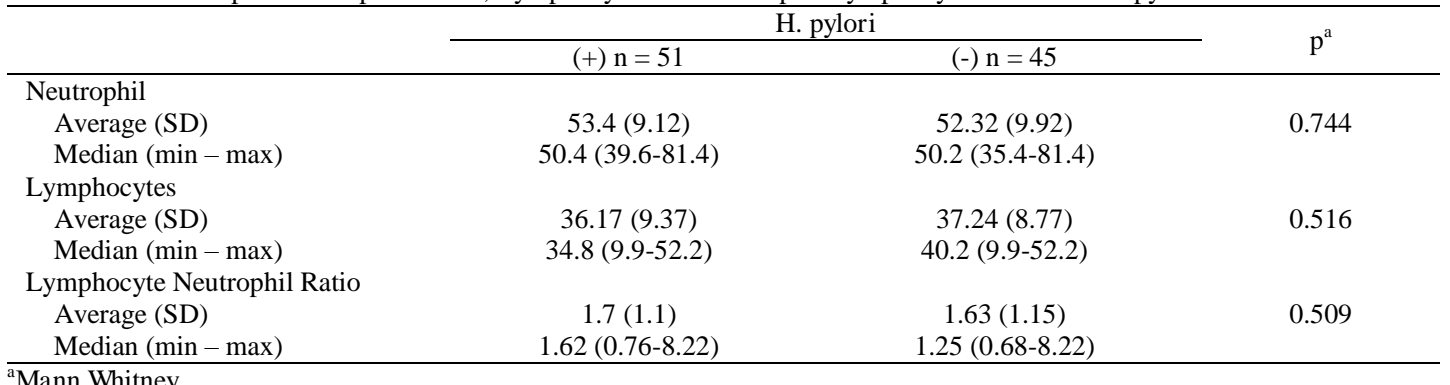

Results The study showed that the mean neutrophil level in children with H. pylori infection (+) was $53.4(\mathrm{SD}=9.12)$ and the mean neutrophil levels in the group of children with $\mathrm{H}$. pylori infection (-) was 52.32 (SD = 9.92). By using the Mann Whitney test, it was found that there was no significant relationship between neutrophils and $H$. pylori infection $(p=0.744)$.

The results of the study showed that the average lymphocyte level in children with $\mathrm{H}$. pylori infection (+) was 36.17 (SD = 9.37) and the mean lymphocyte levels in the group of children with $\mathrm{H}$. pylori infection (-) was 37.24 ( $\mathrm{SD}=8.77$ ). By using the Mann Whitney test, it was found that there was no significant relationship between lymphocytes and $\mathrm{H}$. pylori infection $(\mathrm{p}=0.516)$. 
The results of the study showed that the mean ratio of neutrophil to lymphocyte in children with $\mathrm{H}$. pylori infection $(+)$ was $1.7(\mathrm{SD}=1.1)$ and the mean ratio of neutrophil to lymphocyte in the group of children with $\mathrm{H}$. pylori infection (-) was 1.63 ( $\mathrm{SD}=1.15$ ). By using the Mann Whitney test, it was found that there was no significant relationship between the ratio of neutrophil lymphocytes and H. pylori infection $(\mathrm{p}=0.509)$.

\section{Discussion}

Several epidemiological research results show that the prevalence of $\mathrm{H}$. pylori infection in industrialized countries is low, whereas in developing countries it is quite high (Atayan and Hacisalihoglu., 2017). Research on the relationship between clinical manifestations and H. pylori infection in children has not been as much as done in adults. Several data have been reported showing that $\mathrm{H}$. pylori infection in children is mostly asymptomatic or shows non-specific gastrointestinal symptoms (Gormally, et.al., 1995). Several clinical symptoms are considered as alarm symptoms such as malabsorption with weight loss, growth disorders, iron deficiency anemia, recurrent diarrhea, and malnutrition (Oderda and Cadranel., 1998).

This study showed that the majority of children with H. pylori infection were female sex with a total of 35 people (57.4\%) compared to male sex with a total of 16 people (45.7\%). This is different from the research conducted by Zhu, which showed, from 5417 samples that underwent UBT examination, there were 3435 (63.41\%) sample with H. pylori (+) where it was stated that there were more women with H. pylori than men $(64,47: 35,63)$ (Zhu, et.al., 2014). However, it is different from the research conducted by Suparyatmo at RSUD DR Muwardi Solo which showed the prevalence of $\mathrm{H}$. pylori infection where in the male group, which H. pylori infection was found in 34 cases (7.5\%) in the male group, and 35 cases in the female group. (6.9\%). This study did not find a significant relationship between gender and the incidence of $\mathrm{H}$. pylori infection $(\mathrm{p}=0,270)$. This may be due to differences in the sources of population data used (Suparyatmo. Soewignjo, and Mutaqin., 1995).

This study also showed that the mean age of children with H. pylori (+) was 11.55 years, meanwhile, the mean age of children with $\mathrm{H}$. pylori (-) was 11.79 years. The study conducted by Jang, et.al, stated that the prevalence of Helicobacter pylori infection was higher in older children, and there was a significant relationship between age and the incidence of Helicobacter pylori infection $(\mathrm{p}=0.018)$. Research conducted by Suparyatmo showed that in the age group 5-9 years the prevalence of $\mathrm{H}$. pylori was $3.7 \%$ out of 187 children, while in the age group 10-14 years, it was $12 \%$ or 26 children out of 190 children. This is similar to the findings of this study where it was found that as the age of a child increases, the prevalence of $\mathrm{H}$. pylori infection increases (Suparyatmo., Soewignjo, and Mutaqin., 1995). Although this study did not find a significant relationship between age and the incidence of $\mathrm{H}$. pylori infection $(\mathrm{p}=0.727)$. Many epidemiological studies involving children show that $\mathrm{H}$. pylori infection occurs in early childhood and infection rates increase at about 5-7 years of age. At that age, children usually begin to enter group life, for example kindergarten or elementary school, which may increase the possibility of person-to-person transmission (Park, et.al., 2021 and Zabala, et.al, 2017) .

In a study conducted by Syam, the H. pylori infection rate among Malays in Malaysia was only $19.6 \%$ and was significantly lower than that of the Chinese and Indian populations. In contrast, the Javanese have a very low H. pylori infection rate, only $2.4 \%$. According to Syam, the 
five largest islands in Indonesia show a high prevalence of $\mathrm{H}$. pylori in Sumatra. The prevalence of $\mathrm{H}$. pylori infection among Malays is low, with no $\mathrm{H}$. pylori in some ethnic groups, such as Acehnese and no $\mathrm{H}$. pylori among Javanese. However, a very high rate of $\mathrm{H}$. pylori infection was observed among the Batak people (Syam, et.al., 2021). In this study, Indian and Papuan tribes showed $100 \%$ experiencing H. pylori, followed by Javanese and Minang tribes respectively $60 \%$, Batak 58.5\%, Acehnese 54.5\%, Malays 29.9\% and Chinese $25 \%$. Nevertheless, this study showed that there was not any significant relationhip between the ehtnics and the incidence of H.pylori infection $(\mathrm{p}=0.228)$.

This study also showed that there was no significant relationship between socioeconomic status and the incidence of H. pylori infection $(\mathrm{p}=0.513)$. However, according to Vandenplas, a crowded environment and a low socio-economic environment are considered as risk factors for $\mathrm{H}$. pylori infection in children. Infected parents, especially mothers, may play a role in the transmission of H. pylori in the family (Vandenpla and Hegar., 1999).

H. pylori causes local inflammation in the stomach and a systemic humoral immune response. Most cases have asymptomatic chronic inflammation. H. pylori infection, which has a high morbidity rate, is recognized as a worldwide problem and the most frequent cause of chronic gastritis (Malaty., 2007). H. pylori attracts neutrophils and lymphocytes with several chemotactic proteins released in the stomach. Several substances secreted by mononuclear cells and neutrophils induce mucosal inflammation and thereby cause gastritis. In conclusion, gastric mucosa is infiltrated by neutrophils, macrophages, and lymphocytes in addition to several signaling cytokines, and low-grade subclinical systemic inflammation occurs. H. pylori is mainly associated with severe gastric diseases such as chronic gastritis, peptic ulcers, gastric lymphoma, can gastric cancer (Ruggiero., 2010and Kusters, van Vliet dan Kuipers., 2006).

The results of the study showed that the mean neutrophil level in children with H. pylori infection (+) was 53.4. The accumulation of neutrophils in the intraepithelial gastric mucosa has a close relationship with damage to the gastric mucosa and the intensity of H. pylori infection. Thus, the higher the degree of damage to the gastric mucosa, the more neutrophils accumulate in that area. H. pylori infection can trigger the release of inflammatory mediator cells such as neutrophils, eosinophils, and lymphocytes. H. pylori can cause mast cell degranulation in the infected gastric mucosa. In the journal Pathology of Nepal (2011), stated that the accumulation of mast cells in the gastric antrum mucosa in positive patients with $\mathrm{H}$. pylori infection compared to people who were negative for $\mathrm{H}$. pylori infection (Amatya., 2011). In a study conducted by MN (Tanko et.al., 2008), there was a relationship between H. pylori infection with neutrophil activation and chronic gastritis. The study also found that the higher the intensity of $\mathrm{H}$. pylori infection, the more neutrophils will activate. On average, $90-100 \%$ of cases of duodenal ulcer and 60-100\% of gastric ulcer cases are caused by H. pylori infection (Ruggiero, 2010). However, this study did not find a significant relationship between neutrophils and H. pylori infection $(\mathrm{p}=$ 0.744). In the measurement of lymphocytes, the results of the study showed that the mean lymphocyte levels in children with $\mathrm{H}$. pylori infection $(+)$ was $36.17 \pm 9.37$ and the mean lymphocyte levels in the group of children with H. pylori infection (-) was $37.24 \pm 8,77$, but no significant association was found between lymphocytes and $\mathrm{H}$. pylori infection $(\mathrm{p}=0,516)$.

The ratio of neutrophil to lymphocyte is one of the markers of infection that can be used as a predictor of bacterial infection. This occurs because of delayed apoptosis and growth hormone 
stimulated by stem cells resulting in an increase in neutrophils and accelerated apoptosis accompanied by redistribution of lymphocytes so that neutrophils might increased as well (Malaty., 2007, Kusters., 2006; Amatya., 2011). Research by Holub, et al (2012) stated that the Neutrophil Lymphocyte Ratio is a good parameter to predict bacterial infection compared to WBC, CRP and the number of neutrophils (Tanko, et.al., 2008). The results showed that the mean neutrophil lymphocyte ratio in children with $\mathrm{H}$. pylori infection $(+)$ was $1.7 \pm 1.1$ and the mean neutrophil lymphocyte ratio in the group of children with $\mathrm{H}$. pylori infection (-) was $1.63 \pm$ 1.15.There was no significant relationship was found between the ratio of neutrophil lymphocytes and H. pylori infection $(\mathrm{p}=0.509)$.

Several studies reveal that there are several factors related to changes in the value of neutrophils or lymphocytes in a person which will be a confounding factor in this study, including age, sex, body mass index, autoimmune diseases and immunodeficiency diseases. The neutrophil/lymphocyte ratio is influenced by the absolute value of neutrophils and lymphocytes. Neutrophils as an innate immune response and lymphocytes as an adaptive immune response. Several factors influence the presence of neutrophilia and lymphocytopenia that can occur in conditions of corticosteroid use, immunocompromised conditions, malignancy, sepsis, trauma, and critical illness (Kocyigit, et.al., 2013). In this study, there was no significant difference between age, sex, body mass index (weight and height) and the Neutrophil Lymphocyte Ratio. Researchers also did not examine further related to other confounding factors such as autoimmune disease, or history of drug use. Good socio-economic factors, parental education level and parental occupation are factors that influence nutritional status in this study. Good nutritional status affects the quality of immune status. One of the factors that affect immune status is nutritional factors, the better the nutrition obtained, the better the immune response (Carpenter, et.al., 2011).

In this study, it was found that from 60 subjects there were $86.5 \%$ children with good socioeconomic levels. According to Supriasa (2012), improving nutritional status in the community is closely related to socio-economic status problems, which in this case require policies that guarantee every member of the community to obtain sufficient quantity and quality of nutrition. Nutritional problems arise due to food security problems at the household level, namely the ability of households to obtain food for all members, so that nutrition problems are no longer merely a health problem but also a problem of poverty, equity and employment opportunities. This is in line with the opinion of Marimbi (2010), in which socio-economic factors of the family will also determine the dishes served for the family on a daily basis, both in terms of quality and quantity of food. It can be seen that children with high socioeconomic status fulfill their nutritional needs very well compared to children with low socioeconomic status. Adequate nutrition will play a role in preventing the occurrence of various diseases (Santoso, 2004). Deficiency or excess of one element of these nutrients will cause abnormalities or disease because it will directly determine nutritional status (Aritonang and Albiner, 2003). Nutritional status is influenced by food intake and disease, especially infectious diseases. Insufficient nutritional intake will lead to decreased immune status where this situation will make it easier for children to be infected with diseases (United Nations Children's Fund, 1998). Gibney et al (2005) stated that people with poor nutritional status are more likely to experience diseases and are also more likely to suffer from all these diseases with a longer duration. People who are malnourished are more likely to experience symptoms from common infections that debilitate the body. It is not clear that specific 
macronutrient or micronutrient deficiency states result in increased morbidity due to infection (Gibney, et.al, 2005).

\section{Conclusion}

No significant relationship was found between the ratio of neutrophil lymphocytes and $\mathrm{H}$. pylori infection $(p=0.509)$. In this study, there are several weaknesses that cause the results obtained are still not consistent with the results of previous studies. One of them is the Neutrophil Lymphocyte Ratio is strongly influenced by various factors, although the research is multi-center in which the research sample is taken from several populations, different socio-economic and cultural backgrounds greatly affect the results obtained. Different methods of examination and diagnosis of $\mathrm{H}$. pylori infection are different, differences in the epidemiological characteristics of population sources with different social and economic backgrounds. Based on these, the author suggests that future researchers can use samples from several research locations, so that the research samples obtained can be more heterogeneous and future researchers should focus more on several confounding factors, both those that can affect the neutrophil lymphocyte ratio and those that are risk factors for H.pylori infection.

\section{Acknowledgments}

The author would like to thank all the staff in the Faculty of Medicine, University of North Sumatra for the extensive support during the study.

\section{References}

Aritonang, E. Siagian Albiner., 2003. Hubungan Konsumsi Pangan dengan Gizi Lebih pada Anak TK di Kotamadya Medan. Lembaga Penelitian Universitas Sumatera Utara

Atayan, Y. and Hacisalihoglu, P., 2020. The correlation between tissue Helicobacter pylori severity and the increase in serum neutrophil/lymphocyte ratio in patients with active chronic gastritis. Biomedical Research 2017, 11(28), pp.4874-4877

Carpenter KC, Strohacker K, Breslin WL, Lowder TW, McFarlin BK. (2011, April). Voluntary wheel running during weight loss leads to differential changes in monocytes, compared to forced treadmill running. International Journal of Exercise Science, 2(3)

Gibney, Michael J., Margetts, Barrie M., Kearney, John M., Arab, Lenore. 2005. Gizi Kesehatan Masyarakat. Buku Kedokteran EGC: Jakarta.

Gormally SM, Prakash N, Durnin MT, et al. Association of symptoms with Helicobacter pylori infection in children. J Pediatr 1995; 126:753-6.

Guclu, M. and Agan, A., 2017. Association of Severity of Helicobacter pylori Infection with Peripheral Blood Neutrophil to Lymphocyte Ratio and Mean Platelet Volume. Euroasian Journal of Hepato-Gastroenterology, 7(1), pp.11-16.

Holub M, Beran O, Kasprikova N, Chalupa P. Neutrophil to lymphocyte count ratio as a biomarker of bacterial infections. Cent Eur J Med. 2012;258-61.

Jafarzadeh, A.; Akbarpoor, V.; Nabizadeh, M.; Nemati, M.; Rezayati, M.T. Total leukocyte counts and neutrophillymphocyte count ratios among Helicobacter pylori-infected patients with peptic ulcers: Independent of bacterial CagA status. Southeast Asian J. Trop. Med. Public Health 2013, 44, 82-88.

Kocyigit I, Eroglu E, Unal A, Sipahioglu MH, Tokgoz B, Oymak O et al. Role of neutrophil/lymphocyte ratio in prediction of disease progression in patients with stage-4 chronic kidney disease. Journal Nephrology 2013; 26(02): $358-65$.

Kusters JG, van Vliet AHM, Kuipers EJ. Pathogenesis of Helicobacter pylori infection. Clin Microbiol Rev 2006 Jul;19(3): 449-490.

Liu, C.; Li, X. Stage-Dependent Changes in Albumin, NLR, PLR, and AFR are correlated with Shorter Survival in Patients with Gastric Cancer. Clin. Lab. 2019, 65 
Malaty HM. Epidemiology of Helicobacter pylori infection. Best Pract Res Clin Gastroenterol 2007;21(2):205-214.

Marimbi. 2010.Tumbuh Kembang, Status Gizi dan Imunisasi Dasar pada Balita.Yogyakarta : Nuha Medika

Marshall B.J. Epidemiology of Helicobacter pylori in Western countries. Dalam: Hunt RH, Tytgat GNJ, penyunting. Helicobacter pylori. Basic Mechanism to Clinical Cure. Edisi ke-1. London: Kluwer Academic Pub, 1994. h. 75-80.

Oderda G, Cadranel S. Management of Helicobacter pylori in children. Gut 1998; 42:1-3

Park J, Jun J, Seo J, Youn H, Rhee K. Changing prevalence of Helicobacter pylori infection in children and adolescents. Clinical and Experimental Pediatrics. 2021;64(1):21-25.

Ruggiero P. Helicobacter pylori and inflammation. Curr Pharm Des 2010;16(38):4225-4236

Santoso, S. 2004. Kesehatan dan Gizi. Rineka Cipta: Jakarta.

SR KC, GL Amatya. Association of mast cells with helicobacter pylori infection in the antral mucosa - Journal of Pathology of Nepal, 2011

Supariasa, 2012. Penilaian Status Gizi. Jakarta: Penerbit Buku Kedokteran EGC

Suparyatmo JB. Soewignjo S, dan Mutaqin Z. Survei seroepidemiologik infeksi Helicobacter pylori di Surakarta. Makalah lengkap dari kumpulan Seminar Nasional Helikobakter Pilori dan Penyakit Gastroduodenal. Denpasar, Bali 25 Maret 1995. h. 96-7.

Syam et al. RESEARCH Helicobacter pylori in the Indonesian Malay's descendants might be imported from other ethnicities, Gut Pathog (2021) 13:36

Tanko MN, Manasseh AN, Echejoh GO et al: Relation between Helicobacter pylori, infammatory (neutrophil) activity, chronic gastritis, gastric atrophy and intestinal metaplasia. Niger J Clin Pract. 2008 Sep;11(3):270-274.

United Nations Children's Fund. 1998. The State of The World's Children. Oxford University Press: Oxford.

Vandenplas Y, Hegar B. Helicobacter pylori infection. Acta Paediatr Tw 1999;40:212-24.

Yulida E, Oktaviyanti IK, Rosida L. Gambaran derajat infiltrasi sel radang dan infeksi Helicobacter pylori pada biopsi lambung pasien gastritis. Berkala Kedokteran. 2013; (1):47-58.

Zabala Torrres B, Lucero Y, Lagomarcino AJ, Orellana-Manzano A, George S, Torres JP, et al. Review: prevalence and dynamics of Helicobacter pylori infection during childhood. Helicobacter 2017;22.

Zhu Y, et al. Risk Factors and Prevalence of H. pylori Infection in Persistent High Incidence Area of Gastric Carcinoma in Yangzhong city.2014. 